Article

\title{
Empowering Domestic Workers: A Critical Analysis of the Belgian Service Voucher System
}

\author{
Sarah Mousaid ${ }^{1, *}$, Kim Bosmans ${ }^{1}$ and Christophe Vanroelen ${ }^{1,2}$ \\ 1 Department of Sociology, Interface Demography, Vrije Universiteit Brussel, 1050 Brussels, Belgium; \\ Kim.bosmans@vub.ac.be; (K.B.); cvroelen@vub.ac.be (C.V.) \\ 2 Health Inequalities Research Group, Employment Conditions Knowledge Network (GREDS $\backslash$ Emconet), \\ Universitat Pompeu Fabra, 08002 Barcelona, Spain \\ * Correspondence: sarahmousaid@hotmail.com
}

Received: 2 November 2017; Accepted: 18 December 2017; Published: 20 December 2017

\begin{abstract}
Domestic cleaners lack bargaining power, which can prevent them from being in control of their work quality. The 'service voucher system' is expected to change the power position of domestics. This is expected because the system is formalized by the Belgian government and organized through a triangular employment relationship between the domestic, the service voucher company (the employer), and the customers. This study draws on 42 interviews with immigrant and native service voucher cleaners. It probes into how the employment relationship with the company affects the domestics' perceived power to bargain with customers about determinants of the work quality. Based on the results, policy recommendations are made to further empower domestic cleaners in the relationship with their customers and to help them safeguard their work quality.
\end{abstract}

Keywords: Belgium; domestic work; immigration; formalization; service voucher system; the employment relations; the quality of work

\section{Introduction}

It is well established that domestic workers frequently have to deal with a poor 'quality of work'. In this context, 'work quality' refers to the employment conditions (e.g., employment contracts, income, working hours) as well as the intrinsic characteristics of the work task (e.g., physical demands, psychosocial demands, variation of work tasks) [1].

This largely results from the fact that characteristics of domestic work and of the domestic workers can prevent the latter to bargain in their relationship with customers [2]. The bargaining power of domestics is low for diverse reasons. Firstly, domestic workers are often financially dependent on their customers because of limited other labor market opportunities. Secondly, the personal, emotional, and servile relationships in domestic work can prevent domestics from enforcing their rights. Thirdly, domestic work often occurs under informal employment relationships, and this can impede domestics to enforce their rights as well.

The Belgian service voucher system is expected to tackle the lack of bargaining power of domestics because it is a formal employment scheme that is organized through a triangular employment relationship between the domestic worker, a service voucher company (the employer), and the customers [2-5].

Yet, studies that investigate workers' bargaining power in the service voucher system, or similar employment schemes in other countries, are lacking. In contributing to the scant research on this subject, the aim of this study is to probe into how practices of the employing company can affect the perceived bargaining power of domestic cleaners in their relationship with customers. More specifically, we shed light on how 'good' as well as 'bad' employer practices can affect the domestic cleaners' perceived power to negotiate over their work quality. In doing this evaluation, special attention is paid to the 
particular situation of domestic cleaners with an immigrant background. The perception of their bargaining power is expected to be low because they tend to combine more disadvantageous social positions: female gender, low skill level, and immigrant status [4]. In first instance, the results of this study are of relevance to Belgian policy makers in order to further improve work quality for the implicated workers. However, since the Belgian Service Voucher System is increasingly referred to as an example in the international literature [6], our findings can also be useful for countries that want to implement a similar employment scheme for formally organizing domestic work.

The following part of this paper presents the background of this study. First of all, it deals with the quality of work in paid household services in general. In addition, it sheds light on the bargaining power of domestics in their employment relationship with customers and employers. Moreover, it focuses on how the service voucher system can change the bargaining power of service voucher cleaners. Thereafter, it presents the methodology used in this study. Subsequently, the results section consists of three parts. The first part explains how the employer can influence the domestic cleaners' bargaining power in terms of the 'employment conditions'. The second part shows how the employers can affect the domestic cleaners' power to bargain about the intrinsic characteristics of the work task. The third section deals with the specific situation of domestics with an immigrant background. Finally, the main conclusions of this article, as well as a number of policy recommendations, are presented.

\section{Background}

\subsection{The Quality of Work in Paid Household Services}

A growing body of literature shows that the 'quality of work' tends to be poor in paid household services and that these jobs involve health risks for the workers [7-10]. Based on previous research of Eurofound, this study defines the 'quality of work' in terms of the employment conditions, i.e., the contractual arrangements between employers and employees (e.g., income, working hours), as well as in terms of the intrinsic characteristics of the work tasks, i.e., the job content and the physical and psychosocial job demands (e.g., autonomy, toxic exposures, workload) [1].

First of all, employment conditions are generally suboptimal. Previous research shows that wages in paid domestic work are generally lower than in most other occupations. Moreover, formal employment contracts are often lacking and job insecurity is high $[3,8]$.

In addition, work tasks are generally of poor intrinsic quality, involving low control over work methods, work schedules, as well as cleaning products and materials. Domestic work is also monotonous work with few opportunities for personal development [3,8]. Moreover, domestic work is physically demanding (e.g., repetitive and fast upper body motions used when scrubbing and mopping, or adopting awkward postures to reach windows or doors) [8,9]. Domestic workers also tend to experience high workload related to tight work schedules, and they have to use toxic products frequently [3]. The poor quality of work is clearly related to elevated health risks for the workers involved. A literature review of 35 studies reveals that cleaning jobs are related to dermatologic diseases, respiratory diseases, musculoskeletal problems, and mental disorders, associated with physical (e.g., awkward postures, prolonged standing) and psychosocial stressors (e.g., monotonous work) [10].

\subsection{The Bargaining Power of Domestics}

The poor quality of work in personal household services largely results from the fact that the workers lack bargaining power in the employment relationship with their customers [2]. In this study, bargaining power refers to the ability of domestic workers to enforce their rights and influence their quality of work. Domestics lack bargaining power for several reasons. They are often financially dependent on their customers because of restricted labor market opportunities. The personal, emotional, and servile relationships in domestic work can also prevent them from enforcing their rights. 
Moreover, domestic work often occurs under informal employment relationships, which constitutes an impediment to enforce their rights $[2,4,11]$.

Domestic workers have limited opportunities in the labor market, which makes them financially dependent on their customers and decreases their power to negotiate. The labor market opportunities of domestics are often restricted because of their low qualifications-but also because of their female gender and their immigrant background [2,4]. In the current knowledge-based service economy, skills or expertise are highly valued in the labor market. By consequence, low-skilled workers have lower degrees of valuable labor power [12]. Yet, the employment opportunities of female immigrants are also limited because of processes of stereotyping and discrimination. Employers appear to base their expectations about individuals' skills and performance on stereotypes about gender and ethnicity, and the skills of women and immigrants are often conceived as being 'less valuable' [13]. For example, female immigrants are considered mainly as partner migrants who are economically dependent on their husband, while their skills and ambitions are often overlooked. Because of these stereotypes, female immigrants are often discriminated in the labor market. Moreover, these stereotypes often intersect with issues of citizenship and residency permits [2,4].

The relationship between domestic workers and customers is also a very personal, one-on-one relationship. Therefore, domestic workers' attempts to enforce their rights can be considered as a breach of the 'special bond' related to this intimate relationship in the eyes of the customer $[2-4,11]$. Furthermore, domestic workers can have a 'servile' relationship with their customers, and the stigma related to that kind of employment relationship can further prevent domestic workers to enforce their rights [14-16].

Moreover, domestic work often occurs under informal employment relationships, and the absence of written contracts decreases the bargaining power of the workers [4].

\subsection{The Service Voucher System and the Empowerment of Domestic Workers}

The Belgian Service Voucher System is an initiative that can affect the bargaining power of domestics in the employment relationship with their customers. In what follows, we firstly outline this service voucher system. Thereafter, we set out how domestic work in the specific context of the service voucher system can affect the bargaining power of domestics.

By implementing the service voucher system on the 1 of January 2004, the Belgian Federal government aimed to formalize paid domestic work, create jobs for low-skilled workers, and improve the work-life balance of dual-earner families [1,2]. The service voucher system is organized in the form of a triangular employment relationship between the domestic worker, the service voucher company (the employer), and a number of customers. In this triangular employment relationship, both the customers and the domestic workers have a contract with the service voucher company. Customers can hire domestic help from that company and pay for the services with vouchers. One voucher, covering one hour of domestic help, costs 9 euro, but because of an additional tax credit, the net price of one hour of service work is 6.03 euro for the customer [5]. The service voucher workers earn between 10.70 euro and 11.37 euro [17].

In this triangular employment relationship, the service voucher company is the official employer of the service voucher worker. The company is responsible for the payment of the worker's wage and for the employment contract that specifies the worker's income and the minimal number of weekly working hours. To guarantee employment stability, the employment contract can only be temporary for up to three months. After three months of consecutive employment with the same employer, the contract turns into one of unlimited duration. Companies are also responsible for the payment of social security contributions [5]. Hence, service voucher workers acquire social security rights similar to other workers in Belgium. These imply, among other things, paid leave, disability pension, unemployment benefits, and old age pension rights. Furthermore, service voucher companies should act as an intermediary to safeguard their workers' health and safety, as well as prevent them from working in an environment where they could be victims of abuse or discriminatory practices [5]. 
The service voucher system is highly subsidized. Of the total amount of 22.04 euro for each voucher that the companies receive, 13.04 euro comes from government subsidies, while only 9 euro stem from customer payments [5].

On one hand, we can expect that the service voucher system can increase the bargaining power of domestics. Firstly, the presence of an intermediary actor (the company) withholds the domestics from being directly dependent on customers for securing their livelihood. Additionally, the presence of an intermediary actor can make the employment relationship less personal and emotional. Moreover, the existence of a legal framework enables the domestic workers to enforce their rights [2-4]. In conclusion, formalizing domestic work through a triangular employment relationship can thus shape more equalized employment relationships and increase the perceived bargaining power of domestics, i.e., enable domestics to enforce their rights and influence their work quality.

On the other hand, most of the service voucher companies (the employers) are situated in the for-profit sector $(63.5 \%)$, and economic considerations may hinder the supposed empowering role of service voucher companies [17]. Under the logic of market economy, we can expect that companies will mainly be interested in taking as much labor power from the workers at the cheapest possible price in order to increase their economic power [18]. Moreover, they can be reluctant to intervene in the employment relationship between workers and customers out of fear for losing customers.

Based on these considerations, this study investigates how the presence of an intermediary actor in the service voucher system can affect the perceived bargaining power of domestic cleaners in their employment relationship with their customers. We focus on the employment conditions as well as on the intrinsic characteristics of the work tasks, while we consider both 'negative' and 'positive' practices. Special attention is paid to immigrant service voucher cleaners. The following section outlines the methodology used for this study.

\section{Materials and Methods}

Our data stems from (qualitative) in-depth interviews with service voucher cleaners. The sample comprises 42 domestic cleaners of native (15) and immigrant origin (27) who were employed in the service voucher system at the moment of the interview or in the two years before. Given the large share of women employed in the system (97.4\%) [17], this study only includes female service voucher cleaners.

Respondents were recruited through different channels in order to guarantee the diversity of our sample. Organizations that were active in the service voucher system and that contributed to the recruitment were: a trade union, a number of service voucher companies, and an occupational health practitioner working for a large service voucher company. Chain-referral sampling, starting from our own contacts and from participants in the study, completed the recruitment process.

All interviews were undertaken between February 2012 and October 2014. The respondents could choose to complete the interviews either in their home or in another quiet place.

The interviews were structured by a topic list. The topics covered the different dimensions of the quality of work as described by Eurofound (e.g., contract stability, social security rights, the triangular employment relationship, psychosocial demands, autonomy) [1]. For immigrants, the list consisted of additional topics about the respondent's personal migration history and the process of finding a job after migration. In order to make the interviews appear as a natural conversation, the interviewer focused on two narratives: (1) the life course perspective, emphasizing migration and employment history; and (2) the structure of a typical work day. Additionally, further probing into the stories of the informants procured more detailed information. The languages used in the interviews were Dutch (21), French (17), and English (4).

The duration of the interviews varied between 37 and $112 \mathrm{~min}$. All interviews were digitally recorded, transcribed verbatim, and the transcripts were read through several times. 
All respondents signed an informed consent after being informed of the details of the study. Ethical approval was obtained from the Ethical Commission of the University Hospital of the 'Vrije Universiteit Brussel' (B.U.N. 143201316163).

To analyze the data, the researchers paid attention to the perceptions and feelings that people associate with their experience and not only to mere observations of the experience itself $[19,20]$. The researchers aimed to reveal how practices of service voucher companies affected the employment relationship between domestics and customers, as well as how domestics perceive that these practices (dis)empower them in being able to bargain for better employment and intrinsic working conditions. In the first place, coding the data through thematic content analyses guided the analytic process [21,22]. The deductive coding process by means of a coding scheme was based on the different (sub) dimensions of the quality of work [1]. More specifically, codes were related to the employment relationships (relationships with the customers and the employer), employment conditions (e.g., wage, working hours), or intrinsic job characteristics (e.g., physical demands, autonomy). Inductive analyses complemented the deductive coding process. This additional step helped the researchers to fully grasp the complexity of the research topic, because it allowed for the inclusion of elements that the respondents considered meaningful (e.g., the importance of work, their immigrant background) [21]. The researchers selected relevant text fragments by crossing codes (queries) on the employment relationships and work quality characteristics (e.g., the relationships with customers and psychosocial job demands). NVIVO $10 \mathrm{TM}$ software was used for the coding and querying process.

The results section includes quotes to illustrate the most important findings. These quotes are labelled with pseudonyms, which the first and the second authors gave to the informants. The labels also inform the reader about the country of origin of the respondents. If a partner or a family member was participating in the conversation, this is also mentioned in the labels. Given the fact that only four interviews were conducted in English, most quotes in this article are translations.

\section{Results}

Below, we shed light on how 'good' as well as 'bad' employer practices can affect the domestics' perceptions of their power to bargain about the employment conditions and the more intrinsic characteristics of their work task. We pay special attention to the particular situation of domestics with an immigrant background.

\subsection{Employers' Practices, Employment Conditions, and Worker's Empowerment}

The interviews show how companies can safeguard the stability of employment in terms of contract, earnings, and work schedule. For instance, some companies have a severe cancellation policy for their customers. They oblige their customers to pay for the service if they have cancelled without prior notice. This not only assures the revenue of the service voucher company, but it also prevents that customers treat domestic work as disposable employment.

Some companies also propose that the cleaners do other work as a replacement for the cancelled assignment (e.g., ironing at the company if this is possible, or cleaning at another address).

The company prefers everyone to be happy. My mother has no problems for the moment. If she has no clients, the company finds other work for her, such as ironing. So she does not lose the working hours [... ] she keeps the same program, she has 25 h every week. It is the same every week. (Elisabeta, Romania, with her daughter operating as a translator)

The interviews show that domestic cleaners perceive that their employment opportunities are high if their company safeguards their employment stability, and how this perception increases their power to bargain. The citation of Ellen illustrates this mechanism:

Are you required to look for your clients?

No, that is the responsibility of the employer. Or if you're dealing with a certain client that you do not get along with, you may discontinue visiting those clients. That's the benefit of our employer. 
Because sometimes I work in certain homes and the situation is unbearable. [ ... ] At the start of this year I had a customer that treated me like dirt. Then I immediately went to my employer and I said 'I won't ever return to that customer'. (Ellen, Belgium)

In contrast, the interviews also reveal the 'bad practices' that companies apply. Some companies do not have a severe cancellation policy for their clients. Customers then regularly cancel assignments, as Gladys testifies:

\section{Does it often happen (that customers cancel)?}

Maybe two times a week.

So is it difficult for you to know (your wage in advance)?

Yes, yes, yes but it is like that in the service voucher system. (Gladys, Angola)

Gladys and several other interviewees said that their company does not provide replacement work when cancellations occur. Instead, the company (partly) withholds the worker's wage.

A related well-known, though illegal, practice is the use of 'variable supplements' to permanent part-time contracts. For example, some companies supplement a $20 \mathrm{~h}$ part-time contract with a variable additional number of working hours, depending on the level of demand from customers. This practice is not in line with the 'spirit of the service voucher legislation', which aims to provide stable employment.

\section{Do you have a contract of unlimited duration?}

Yes it is unlimited. It is a bit of a stupid system. It is an unlimited contract but I have to sign it every week because if you work for the service voucher system, you have to go to people. For example, this week I work for those people, but maybe next week I won't. (Angelika, Poland)

The interviews also illustrate that if the company declines to provide an alternative when problems arise, then the domestic cleaners perceive that their employment opportunities are low. This decreases their perceived bargaining power, as Rania's citation shows:

There are clients that take advantage of their household help. They say (with a bossy tone) 'Remove the armchair, remove this'. That is why I have pain in my back now. But I just continue working ... I don't talk. [ ... ] In the past I lost clients when I said 'No, I don't do this'. It is like that.

And how does your employer react when you have problems with a client?

Sometimes he looks for another client, sometimes he doesn't. (Rania, Morocco)

\subsection{Employers' Practices, Intrinsic Working Conditions, and Worker's Empowerment}

Companies should also act as intermediary actors to safeguard the workers' health and safety. Yet, the service voucher legislation does not further specify this 'intermediary role'. Consequently, the interviews show that companies comply with that role in several ways. For instance, some companies determine rules that define the work equipment as well as the cleaning products that the worker is allowed to work with. Sometimes a company representative also visits the work site or contacts the customer if the domestic cleaner has reported any problems.

Sometimes clients ask you things that are impossible to do in the contracted amount of time. The person that takes care of us then contacts these clients to ask them whether they can adapt their requirements. I feel that in the company the interests of the workers are put before those of the customers. They take care of us first and then of the customers. (Jenica, Romania)

Every time that we go to a new customer our coach checks whether everything is ok. She controls whether the work equipment is ok and she comes to meet the customers and to ask them if they have special requirements. [ ... ] We are not allowed to work with toxic products or with caustics such as bleach. That's why she also checks if all the cleaning products are safe. (Cristina, Moldova) 
The interviews show that if the service voucher company acts as an intermediary, then the domestic cleaners feel that they have more power to bargain about their intrinsic working conditions:

If customers say 'Audrey I see that the toilet is not very clean'. Then I can say 'Ok, I used a multi-purpose cleaner instead of this product. Maybe I can use the product that you want me to use, but then I want goggles and gloves' (smiles). Yes, we had to say that. We learned it in the training. I didn't know that we could say it, but we have the right to say 'I cannot use this without goggles and gloves'. (Audrey, USA)

The interviews also demonstrate that some companies effectively try to tackle the social stigma associated with domestic work. This can also empower domestic cleaners to bargain for better employment and intrinsic working conditions [4].

We had it for two days (training) and it was good. [ ... ] The woman that came to teach us was also a good person. She felt our pain. She said 'You shouldn't see yourself so low because you are cleaning. You are a helper! Don't call yourself a cleaning woman. You are a household helper. You help them. They should respect you, because if you don't do the cleaning for them, they can't do it themselves. You are a very important person'. (Latoya, Nigeria)

In contrast, the interviews show that some companies are reluctant to intervene, and provide poor support for their workers. Some respondents report that their company mainly aims to satisfy the customers.

There was a woman that asked me to clean with warm ammonia. That is very dangerous and it made my eyes smart. After I did it I couldn't open my eyes for three or four days.

\section{And didn't the company tell you that it was dangerous?}

No, the person that was with us said, 'If clients ask you to clean with ammonia, you just put a little bit of it'. (Fouzia, Morocco)

The interviews also demonstrate that some service voucher cleaners are discouraged from reporting problems to their company.

They sent me to a guy. When I went in there it was terror. He was crazy. [ . . ] Everything inside was broken and glued back together [... ] He showed me his bathtub that I had to clean. I found two jerry cans with acid [ ... ] His room was full of wine bottles, he got himself drunk. I called the agency and I said that he was crazy. No one wanted to listen to me. (Bahija, Morocco)

The interviews show that workers who perceive a lack of support from the company have fear to bargain with their customers.

In such situations, customers can misuse their power position in interpersonal contacts with domestics. The interviews show how some customers emphasize their powerful position in order to force the worker to do whatever they ask and under the conditions that they define. Customers do so by stressing that they are the ones who pay for the services of the service voucher cleaner. They believe that they have purchased the right to make the domestic cleaner to perform all the tasks they stipulate [4].

Some customers give you commands. Or they just leave things as they are for months because they expect the cleaning lady to do it. For example, I had to clean the inside of the toilet with a scourer. These are not tasks for us. And then you get the answer 'Yes, we pay you for this'. (Ellen Belgium)

This also often involves domestic cleaners having to deal with excessive work demands during their contracted working time.

It's just increasingly worse and worse every time I go there. It was, from the time I started, always dirty, always dirty. [ ... ]. They leave it in a horrible state and expect miracles to come out of it in $4 \mathrm{~h}$. That's not fun. I think she feels like it's my job to pick up whatever they leave. Whatever they 
leave for me, I'm supposed to do. I feel that's what she thinks. And I don't want to make her angry or make her feel insulted. So I just do it, I try to do it as fast as I can, try to do as much as I can so I don't upset anyone (Allison, USA)

Customers can also emphasize their powerful position by minimizing their expenses when providing cleaning material for the domestic cleaner [2]. The respondents report that some customers only provide cheap, non-ergonomic work equipment. Apart from the fact that it underlines a lack of appreciation, this also unnecessarily increases the physical demands related to domestic work.

There was a lady with a box full of old clothes. She said 'You have to use this'. She cut them very well but it just was not sufficient because they were $t$-shirts. Maybe for cleaning the furniture ok, but not for cleanings the windows and things like that ... And then you explain that it doesn't work and then she buys maybe two small things that you asked, but she said 'No, you have to use all this'. (Solange, Congo)

Moreover, customers often do not acknowledge that their personal space, their home, becomes another's workplace. They emphasize their power over the worker by denying the domestic cleaners' personhood and treat them as if they were invisible. Rollins revealed, after doing participatory fieldwork as a domestic cleaner, that this 'being invisible' can strongly affect workers' sense of human dignity [11]. Not being considered as a person carries a strong connotation of disrespect and clearly adds to the subordination of domestics [11]. Similar feelings were expressed by the respondents in our study, as the testimony of Zineb shows:

Like, for example, she says that if she goes to some customers and she sees something like a panty liner, it feels like a lack of respect. Of course she won't say anything but it feels like she is not respected. It is just the cleaning lady and she can see it. So she would never dare to say anything. She will act like nothing happened, but then she will come home and cry. (Zineb, Morocco, with translator)

\subsection{Immigrants in the Service Voucher System}

The interviews show that having an immigrant background can be an obstacle while bargaining over job quality-related issues. Several mechanisms may be at work.

Some of the immigrants in the interviews have a temporary residence status, which they can lose if they are not working a sufficient number of hours on an annual basis. If their company does not provide them with replacement work, they depend heavily on their current customers to have sufficient hours to maintain their residence permit. This decreases their bargaining power, as the testimony of Zineb illustrates.

There was one customer that my aunt worked for informally before she entered the service voucher system. She felt a bit sorry for her because she was alone and depressed. She counted a lot on my aunt and she liked my aunt a lot. She also said that my aunt was a very important person to her, but at the same time she took advantage of my aunt. One day my aunt called her to explain that she needed to work a certain number of hours to obtain a residence permit. The customer paid my aunt $€ 7.5$ per hour informally but with the service vouchers she needed to pay $€ 8.5$ per hour. So she said 'I do not want to pay more than $€ 7.5$ per hour'. My aunt told her that if the customer would pay her €8.5 per hour with the service vouchers she would work some time for free. Every week she works one hour for free. (Zineb, Morocco, with translator)

The fact that Zineb depends on her customer for her residence permit makes her subordinate in the relationship with her customer. The customer further reinforces her powerful position over Zineb by suggesting the existence of a special bond that goes beyond the simple employment relationship [2]. Anderson and Rollins describe how customers consciously or unconsciously apply this mechanism of 'maternalism' in order to increase power over workers that find themselves in a relatively powerless position. This entails clear advantages for the customer, since it further weakens the worker's 
bargaining power in terms of employment and intrinsic working conditions. In such a situation, any attempt that workers make to enforce their rights may be considered a breach of the 'special bond' in the eyes of the customer [2].

The interviews show how some customers appear to emphasize their 'superior' native origin to force their immigrant domestic cleaner to do whatever they ask.

There was a very heavy piece of luggage and she asked me to remove it. It was heavy so I called, 'please, can you help me carry it?' She answered 'No, you are the housecleaner, you have to carry it! You come here to work, you are the housecleaner!' [ . . . ] But I think the way she does ... you know, some customers are really, really difficult. They treat housecleaners as their slaves, especially when they are black. It is different when a Belgian is cleaning and a black person is cleaning. There are big differences. (Latoya, Nigeria)

Friday I had to go to a customer that was not friendly. She gave me commands all the time 'Do this, do that, do that, do that!!' Once I told her that I studied at the university, but for her I was just Romanian and that's it!!! (Mirela, Romania)

Some immigrant domestics in our interviews started to generate 'ingratiating behavior', i.e., someone who is conscious about his or her inferiority starts to act accordingly [11,23]. They seem to do so because their position as an immigrant domestic cleaner makes them feel subordinate. In our study, most immigrant workers never aspired to work as domestic cleaner. They all ended up in that job because they lacked alternatives in the labor market. Hence, most of them, and certainly those who had previously held a higher social position, see paid domestic work as an inferior job [4]. The fact that they feel subordinate themselves keeps them from engaging in bargaining over their working conditions. This is illustrated by Mirela, who previously worked as an accountant in Romania.

I don't think that a Belgian would change his vacuum cleaner for a foreigner. In my head it's like that. 'Who are you to tell me that I have to change my vacuum cleaner?' (Mirela, Romania)

The perceived bargaining power of immigrant domestics also decreases because their immigrant background limits their employment opportunities. Immigrants' opportunities in the labor market are often restricted-even inside the service voucher system-because some customers do not want a domestic cleaner of immigrant origin [24]:

When I rang the doorbell at a new customer's house, a woman opened the door, but then she immediately closed it again. I rang, I rang, I rang and nobody opened the door. Madame didn't open the door. I called my employer and she said that I had to wait because she was on the phone with the woman. Later my employer called me to say that the customer did not want to have a black housecleaner. (Doris, Ghana)

These processes of 'in-group selection', i.e., a preference for social similarity in terms of gender, ethnicity, or social position, among others, have been extensively theorized in previous studies $[4,11,25]$. Such processes-and immigrants' consciousness of them-make them very dependent on their current customers: losing a customer has far more severe consequences for them, compared with potential consequences for native workers. Therefore, the lack of employment opportunities decreases the immigrant domestics' perceived bargaining power [2,4].

While receiving support of the service voucher company is even more important for domestic cleaners with an immigrant background, this study shows that the immigrant respondents that we interviewed tend to be directed to the least supportive companies. In keeping with other studies about the labor market position of immigrants [26,27], the interviews show that finding a job is often a priority for the immigrants because of economic reasons, but also because the validity of their residence permit often depends on it. In that precarious context, the fact that they lack social contacts, knowledge of the native language, and familiarity with the (social/official) institutions in Belgium directs them not only to domestic work, but also to the least supportive service voucher companies. These mechanisms are illustrated in the following quote: 
My marriage did not succeed. I was a battered woman, like a prisoner, a bird in a cage. After I left my husband, I resided at the safe house. After a while they told me that I had to become independent, they told me that I had to live on my own ... that I had to rent a house. I started to look for a job. I made CVs, but I didn't receive any answers [ ... ]. One day I met a woman that was starting to set up a service voucher company and she needed women to work for her. That is how I found a job in the service voucher system [... I I thought that the service voucher system was the only possibility. When I started to look for a job, I saw that all the women around me were working in the service voucher system. Unfortunately I came across the wrong boss. (Habiba, Morocco)

In conclusion, this study shows that the immigrants that we interviewed perceive a lack of power to bargain with customers because of several mechanisms. At the same time, these mechanisms also direct them to the least supportive companies, which can further affect their power to bargain.

\section{Discussion}

Drawing upon in-depth interviews with 42 service voucher cleaners, this study investigated how the employment relationship with the service voucher company affects the domestic cleaners' perceived bargaining power in relation to their customers. A number of important insights arose from our research. The first important finding concerns the major differences between service voucher companies regarding the efforts they make for guaranteeing stable employment conditions. Our study shows that the poor efforts of some companies often result in a 'dependency relationship' between the domestic cleaner and their customers, pushing the former into a subordinate position. This relationship of dependency negatively affects the perceived bargaining power of the workers. Moreover, some companies do not actively act as intermediaries to safeguard their workers' health and safety. This prevents the workers from defending themselves, while the customers become less restrained from abusing their power over the domestic cleaner. In this context of poor employment relationships, our results are in line with Tomei [28]. She concludes that the introduction of a triangular employment relationship in domestic work can undermine the negotiation power of workers. Especially when the labor supply of domestic workers is limited, directly employed domestic workers can have a strong bargaining position vis-à-vis their customers [28].

By contrast, this study demonstrates that if companies properly adhere to their assigned role, the bargaining power of service voucher cleaners in relation to their customers can effectively increase. This research also demonstrates that the situation of immigrant service voucher cleaners poses particular problems. Our study shows that though receiving support from the company is even more important for immigrants than it is for natives, the immigrant service voucher cleaners in our study are more vulnerable than natives for being directed to less supportive companies.

Keeping in mind that in Belgium around $€ 1.93$ billion of public expenses go to the service voucher system annually, it is time to rethink the system's design [17]. More specifically, the role of the for-profit companies, which function according to a market logic, is an important point of concern from a quality of work perspective. From our point of view, there is something to be said for organizing the service voucher system exclusively through the public sector and the social economy. At least, the for-profit firms that are operating in the service voucher system must strongly engage in reaching goals that go beyond profit-orientation and competition. In that regard, employers must also strive towards values of 'human dignity' in their companies [29]. For the workers, this would imply that companies invest in a worker-oriented organizational culture with fair employment and payment policies, investments in workplace health and safety, as well as equal opportunities for all workers [29]. Based on the 'good' practices in our interviews, this goal, among others, can be reached by providing stable employment conditions - for example through providing replacement work in case of cancellations or problems with a customer. Companies must instruct the customers, inspect the work site, and intervene on behalf of the domestics if discrimination or non-compliance with the rules arises. They should also instruct the domestics, for example through initiatives where experienced multilingual domestic workers coach new employees. Moreover, because domestic cleaners often belong to social groups that usually have 
poor labor market opportunities, these companies can also invest in training for their workers in order to increase their employability for the future. Opening possibilities to attain a new job or to ascend the job ladder are very important for many domestic workers. By enhancing the domestic cleaners' human capital, service voucher companies can effectively increase their labor market opportunities [30,31] and thus their bargaining power in relation to customers [2,4].

Moreover, the presence of 'bad' practices in the service voucher system also relates to the fact that concrete guidelines for defining the role of the service voucher companies are lacking [32]. Therefore, policy makers should better specify the 'intermediary role' of the companies. In addition, they must control the companies more extensively. Companies that do not comply with the requirements need to be effectively sanctioned in order to avoid improper competition. The government can also rethink the financing of the companies. For example, they can subsidize companies based on how they strive towards 'values of human dignity' [29]. The bargaining power of the service voucher cleaners can only increase if companies and the government adhere to the previous recommendations. This is a valuable goal because having bargaining power enables workers to gain control over their job quality, which is important for their physical and mental health [10].

Unfortunately, this study did not gather any insight regarding the situation of live-in domestic workers such as au-pairs. While these groups often have a vulnerable position in Belgium, the service voucher system does not cover these kinds of services [33]. Furthermore, this study included solely the perception of the service voucher cleaners on the employment relationship. Including interviews with customers and employers would have delivered broader insights into the employment relationships in the service voucher system.

In spite of these limitations, this study contributes to our understanding of how formally organized systems for domestic work should be implemented in order to empower the domestic cleaners. In that regard, this study not only provides very valuable information for Belgian policy makers, but also for policy makers in other countries that want to implement a similar system to formalize domestic work.

Acknowledgments: The authors would like to thank the respondents that took part in the interviews and the contact persons of the organizations that helped us to find the informants. We would also like to thank our colleague Kelly Huegaerts for her help with interviewing the domestic cleaners. This work was supported by the SOPHIE-project which has received funding from the European Community's Seventh Framework Program Health (FP7/2007-2013) [grant number 278173].

Author Contributions: Sarah Mousaid and Christophe Vanroelen were engaged with the conceptual development of the fieldwork and the paper. Sarah Mousaid and Kim Bosmans conducted the interviews and analyzed the data. Christophe Vanroelen and Kim Bosmans provided critical feedback on the manuscript. Sarah Mousaid wrote the paper.

Conflicts of Interest: The authors declare no conflict of interest.

\section{References}

1. European Foundation for the Improvement of Living and Working Conditions. Quality of Employment Conditions and Employment Relations in Europe; Eurofound: Dublin, Ireland, 2013.

2. Anderson, B. Doing the Dirty Work? The Global Politics of Domestic Labor; Zed Books: London, UK, 2000.

3. Ahonen, E.Q.; José López-Jacob, M.; Luisa Vázquez, M.; Porthé, V.; Gil-Gonzalez, D.; Maria Garcia, A.; Ruiz-Frutos, C.; Benach, J.; Benavides, F.G. Invisible Work, Unseen Hazards: The Health of Women Immigrant Household Service Workers in Spain. Am. J. Ind. Med. 2010, 53, 405-416. [CrossRef] [PubMed]

4. Hondagneu-Sotelo, P. Domestica: Immigrant Workers Cleaning and Caring in the Shadows of Affluence; University of California Press: Berkeley, CA, USA, 2007.

5. Rijksdienst Voor Arbeidsvoorziening. De Dienstencheques. Available online: http://www.rva.be/nl/ documentatie/infoblad/e8\#h2_13 (accessed on 29 March 2016).

6. Ramioul, M. The Service Voucher System as a Means to Regulate Domestic Cleaning in Belgium. In Proceedings of the RDW Conference: Regulating for Equitable and Job-Rich Growth, Geneva, Switzerland, 3-5 July 2013. 
7. Van den Borre, L.; Deboosere, P. Health Risks in the Cleaning Industry: A Belgian Census-Linked Mortality Study (1991-2011). Int. Arch. Occup. Environ. Health 2017. [CrossRef] [PubMed]

8. Kumar, R.; Kumar, S. Musculoskeletal Risk Factors in Cleaning occupation-A Literature Review. Int. J. Ind. Ergon. 2008, 38, 158-170. [CrossRef]

9. Jungbauer, F.H.W.; Van Der Harst, J.J.; Schuttelaar, M.L.; Groothoff, J.W.; Coenraads, P.J. Characteristics of Wet Work in the Cleaning Industry. Contact Dermat. 2004, 51, 131-134. [CrossRef] [PubMed]

10. Charles, L.E.; Loomis, D.; Demissie, Z. Occupational Hazards Experienced by Cleaning Workers and Janitors: A Review of the Epidemiologic Literature. Work 2009, 34, 105-116. [PubMed]

11. Rollins, J. Between Women: Domestics and Their Employers; Temple University Press: Philadelphia, PA, USA, 1985.

12. Harvey, D. Seventeen Contradictions and the End of Capitalism; Profile Books Ltd.: London, UK, 2015.

13. Browne, I.; Misra, J. The Intersection of Gender and Race in the Labor Market. Annu. Rev. Sociol. 2003, 29, 487-513. [CrossRef]

14. Ashford, B.E.; Kreiner, G.E. "How Can You Do It": Dirty Work and the Challenge of Constructing a Positive Identity. Acad. Manag. Rev. 1999, 24, 413-434.

15. Bosmans, K.; Mousaid, S.; De Cuyper, N.; Hardonk, S.; Louckx, F.; Vanroelen, C. Dirty Work, Dirty Worker? Stigmatization and Coping Strategies among Domestic Workers. J. Vocat. Behav. 2016, 92, 54-67. [CrossRef]

16. Hughes, E.C. Work and the Self. In Social Psychology at the Crossroads; Rohrer, J.H., Sherif, M., Eds.; Harper \& Brothers: New York, NY, USA, 1951; pp. 313-323.

17. Idea Consult. Evaluatie van Het Stelsel van de Dienstencheques Voor Buurtdiensten En-Banen 2013; Idea Consult: Brussels, Belgium, 2014.

18. Wright, E.O. Class Counts; Cambridge University Press: Cambridge, UK, 1997.

19. Creswell, J.W. Qualitative Inquiry \& Research Design. In Choosing among Five Approaches, 2nd ed.; Sage Publications: Thousand Oaks, CA, USA, 2007.

20. Van Manen, M. Researching Lived Experience: Human Science for an Action Sensitive Pedagogy; The University of Western Ontario: London, ON, Canada, 1990.

21. Bernard, H.R.; Ryan, G.W. Analyzing Qualitative Data; Sage Publications: Thousand Oaks, CA, USA, 2010.

22. Patton, M.Q. Qualitative Research E Evaluation Methods; Sage Publications: Thousand Oaks, CA, USA, 2002.

23. England, K.; Stiel, B. "They Think You're as Stupid as Your English Is": Constructing Foreign Domestic Work in Toronto. Environ. Plan. 1997, 29, 195-215. [CrossRef]

24. Idea Consult. Evaluatie van Het Stelsel van de Dienstencheques Voor Banen 2010 Buurtdiensten En-Banen; Idea Consult: Brussels, Belgium, 2011.

25. Kanter, R.M. Men and Women of the Corporation; Basic Books: New York, NY, USA, 1977.

26. Jean, S.; Causa, O.; Jimenez, M.; Wanner, I. Migration in OECD Countries: Labour Market Impact and Integration Issues; Organisation for Economic co-Operation and Development (OECD): Paris, France, 2007.

27. European Foundation for the Improvement of Living and Working Conditions. Employment and Working Conditions of Migrant Workers; European Foundation for the Improvement of Living and Working Conditions (Eurofound): Dublin, Ireland, 2007.

28. Tomei, M. Decent Work for Domestic Workers: Reflections on Recent Approaches to Tackle Informality. Can. J. Women Law 2011, 23, 185-211. [CrossRef]

29. ECG. Common Good Matrix 4.1. Available online: http://balance.ecogood.org/matrix-4-1-en/ecg-matrixen.pdf (accessed on 19 May 2016).

30. Pintelon, O.; Cantillon, B.; Van den Bosch, K.; Whelan, C.T. The Social Stratification of Social Risks: The Relevance of Class for Social Investment Strategies. J. Eur. Soc. Policy 2013, 23, 52-67. [CrossRef]

31. Driver, S.; Martell, L. Left, Right and the Third Way. Policy Politics 2000, 28, 147-161. [CrossRef]

32. Idea Consult. Evaluatie van Het Stelsel van de Dienstencheques Voor Buurtdiensten En-Banen 2008; Idea Consult: Brussels, Belgium, 2009.

33. Organisatie voor Clandestiene Arbeidsmigranten. Huishoudpersoneel: Door een Andere Bril Bekeken; Organisatie voor Clandestiene Arbeidsmigranten: Brussels, Belgium, 2010.

(C) 2017 by the authors. Licensee MDPI, Basel, Switzerland. This article is an open access article distributed under the terms and conditions of the Creative Commons Attribution (CC BY) license (http:/ / creativecommons.org/licenses/by/4.0/). 